\title{
Analysis of Debris Flow Reduction Effect of Check Dam Types considering the Mountain Stream Shape: A Case Study of 2016 Debris Flow Hazard in Ulleung-do Island, South Korea
}

\author{
Man-Il Kim (i) and Namgyun Kim (i) \\ Forest Engineering Research Institute, National Forestry Cooperative Federation, 1800 Dongseo-Daero, Daedeok-Gu, \\ Daejeon 34417, Republic of Korea \\ Correspondence should be addressed to Namgyun Kim; knkblue2@hanmail.net
}

Received 13 May 2020; Revised 10 February 2021; Accepted 26 February 2021; Published 17 March 2021

Academic Editor: bingxiang yuan

Copyright (C) 2021 Man-Il Kim and Namgyun Kim. This is an open access article distributed under the Creative Commons Attribution License, which permits unrestricted use, distribution, and reproduction in any medium, provided the original work is properly cited.

\begin{abstract}
Ulleung-do is a volcanic island located $130 \mathrm{~km}$ east of the Gangwon-do province of South Korea. It is characterized by steep slopes covered with effusive rocks released from multiple volcanic activities. Having accumulated deep colluvium, Ulleung-do Island manifests a high vulnerability to landslides frequently caused by heavy rains or typhoons, debris flow, rockfall, and other disaster hazards in mountainous areas. Therefore, facilities and residential areas located in the lower areas of the island sustain widespread damage. Hence, the installation of check dams designed to reflect the area's local conditions is required to avoid further damage. In line with that, this study analyzes the disaster cases in Ulleung-do's mountain areas and the effect of check dams in debris flow reduction for each type using the KANAKO-2D model. At observation point 1, the result shows that the maximum rate of debris flow is reduced by $48.5 \%$ with an open-type check dam installed and $62.9 \%$ with a closed-type check dam installed from the level without a check dam. For observation point 2, the maximum flow depth decreases by $49.7 \%$ with an open-type check dam and $77.4 \%$ with a closed-type check dam. Thus, this study suggests that the simple installation of check dams in a mountain stream that has experienced debris flow effectively mitigates damage brought by various disasters.
\end{abstract}

\section{Introduction}

Ulleung-do is a volcanic island covered with effusive rocks released from multiple volcanic activities, thereby showing a geologic characteristic with deep colluvium and residual soil layers. For this reason, the island is particularly vulnerable to falling rocks and landslides caused by heavy rains and typhoons. The accumulation of such sediments in a mountain stream has a high possibility of causing debris flow.

Diverse studies have been conducted using different methods for topics related to ground disasters occurring at steep slopes, such as landslides, debris flows, and rock slides caused by rainfalls. As such, studies on the assessment of debris flow susceptibility and hazard with rainfall distributions are widely referenced [1-5]. In addition, previous studies have conducted risk assessments in various ways. Chu et al. [6] developed a tool quantifying the risk of slope failure and identifying the sources of failure risk by combining the limit equilibrium method. Meanwhile, Bathrellos et al. [7] suggested a potential suitability map for urban development in the Xerias stream's drainage basin that has frequently suffered damage from landslides. Moreover, Skilodimou et al. [8] produced assessment maps on hazards from landslides, floods, and earthquakes and subsequently combined them using an analytical hierarchy process and geographical information system (GIS).

Furthermore, studies have been conducted regarding ground disaster characteristics considering diverse factors. Gu et al. [9] suggested a new multi-index assessment method to analyze debris flow risk levels based on the entropy weight-normal cloud method. Salciarini et al. [10] and Kim and Jun [11] examined rainfall conditions and geologic characteristics of landslides for spatial analysis using GIS to assess ground disaster vulnerability and risk. Meanwhile, 
Song and Hong [12] and Chae et al. [13] conducted a study on landslide-triggering characteristics using different geological and soil features and rainfall conditions. Furthermore, Kim and Chae [14] analyzed the landslide-triggering characteristics considering all the three factors, such as topography, geology, and rainfall.

The slope stability analysis method is also used to assess whether a steep slope is susceptible to ground disasters. For some studies, the method reflects precipitation factors, such as pore water pressures and rainfall infiltration rates. Wang et al. [15] suggested a stability assessment based on two parameters (cohesion and internal friction) and a four-level back analysis method using in situ monitoring results. On the one hand, Vassallo et al. [16] presented a method for three-dimensional slope stability while considering the influence of rainfall by pore water pressure. On the other hand, Cha and Kim [17] used extreme rainfall conditions on the infinite slope stability analysis equation to estimate the points causing a landslide. Meanwhile, Santoso et al. [18] and Ali et al. [19] suggested a landslide warning system based on moist contents that vary with the amount of rainfall's ground penetration. In addition, Yu [20] and Lee et al. [21] assumed that the soil layers were saturated with rising groundwater levels instead of being influenced by ground infiltration before they analyzed the landslide risk. These studies provide essential information in understanding the characteristics and factors that contribute to ground disasters on steep slopes.

The study area, Ulleung-do and the bedrock outcrops, covers the surface to a large extent and is composed of volcanic breccia and trachyte. These rocks are lithologically susceptible to chemical and physical weathering, increasing the risk of falling rocks and landslides within the island [22]. Previous studies that covered similar subjects include the characterization of residual volcanic soil in Tenerife, Spanish Canary Islands; the limit equilibrium analysis on the Las Colinas landslide in El Salvador that was based on the collected geological, geomorphological, and geophysical data [23]; the spatio-temporal analysis on shallow landslides at Mt. Aso, Japan [24]; and the characterization of residual volcanic soils of a landslide at Canary Islands [25].

In South Korea, Bae et al. [26] screened out seven landslide-triggering risk factors (bedrock, slope, slope length, age and diameter class of forest, aspect, slope position, and slope form) and drew a diagram to predict the occurrence of landslide risks. Moreover, Lee et al. [27] analyzed the precipitation and temperature characteristics of Ulleung-do Island, and Seo et al. [28] assessed the risks of falling rocks in the northeastern part of the island. Other related studies include an elastic wave exploration, which is used as one of the geophysical prospecting techniques [29]; a magnetic survey [30]; an analysis on geological distribution and origin of Ulleung-do Island using resistivity survey [31]; a characterization of the discontinuity surface development of volcanic rocks to design a rockslide prevention plan of Ulleung-do Island [32]; a preparation of flow accumulation map and slope failure susceptibility map for Ulleung-do Island using multibeam data [33]; and an analysis of infinite slope safety to assess the slope stability in Ulleung-do Island with [34]. These studies analyzed the island's geological characteristics and provide risk assessment data focusing on landslides and rockslides.

Other studies have analyzed the island's precipitation and climate, but there are insufficient studies that discuss mountain disasters from localized heavy rains and typhoons. For this reason, the present study analyzed rainfall events related to mountain disasters in Ulleung-do Island between 2002 and 2016. The KANAKO-2D numerical model was applied, focusing on areas that have experienced damage from debris flows caused by typhoon "Lionrock" in August 2016. Moreover, this study aims to identify the debris flows' characteristics and assess the effects of installing check dams for debris flow control.

\section{Methodology}

2.1. Steep Slope Disasters in Ulleung-do Island. Ulleung-do Island is the ninth largest island in South Korea, located on the East Sea, $130 \mathrm{~km}$ east of the land (Figure 1). It is a volcanic island with an area of $72.86 \mathrm{~km}^{2}$ and its highest point is Seonginbong Peak, at $900 \mathrm{~m}$ above sea level. On average, the island is $637 \mathrm{~m}$ above sea level, with a relatively steep slope in a limited area with a mean value of $35.6^{\circ}$. Its soils are composed of trachyte, basalt, and tuff, which are the parent rocks of this area, showing a high risk of sinking and other ground activities leading to rockslides and landslides $[16,24]$.

Ulleung-do Island's most critical mountain hazards, such as landslides, debris flows, and rockfalls, from 2002 to 2016, are summarized in Figure 1 and Table 1.

Most of the disasters on steep slopes were seen around the Ilju Road on the island, directly or indirectly affected by large-scale rockfall and landslides in the upper natural mountains. Commonly, the construction of a coastal road in a volcanic island requires bedrock to be cut off or parts of the shore filled up. For this reason, rock shed tunnels in Ulleung-do Island were installed mostly in high-risk sections to prevent direct damage from falling rocks. In August 2016, typhoon "Lionrock" caused landslides and debris flow in the vicinity of the Piam (rock shed) Tunnel.

The areas from Sadong-ri, Ulleung-eup, to Taeha-ri, Seomyeon, which are small but relatively populated towns with concentrated facilities, experienced the most damage because the Ilju Road construction along the coastal line increased the area of the steep slope to a large extent. This exposed section in a mountainous area was weathered by the typhoon's rotational direction, in addition to its topographic characteristics, contributing to the landslides that occurred.

2.2. Analyzing Steep Slope Disasters and Rainfall Events. For 15 years, when the area experienced frequent mountain disasters from 2002 to 2016, its average annual precipitation was $1,694.6 \mathrm{~mm}$, with a monthly average of $609.1 \mathrm{~mm}$ from July to September, which accounts for $36 \%$ of the yearly mean (Figure 2). As a result of comparing the history data between steep slope disasters and precipitation, it was found that all the hazard cases that have been reported since 2002 



Figure 1: Major mountainous disasters in Ulleung-do Island for 15 years from 2002 to 2016.

TABLE 1: Major steep slope disasters in Ulleung-do Island.

\begin{tabular}{|c|c|c|}
\hline Date & Cause & Details \\
\hline Jul. 18, 2002 & $\begin{array}{l}\text { Localized heavy } \\
\text { rainfall }\end{array}$ & Landslides in Cheonbu-ri, Buk-myeon, and Uleung-gun \\
\hline Sept. 6, 2005 & Typhoon "Nabi" & Landslides in the upper part of Namseo Tunnel, Seomyeon, and Uleung-gun \\
\hline $\begin{array}{l}\text { Aug. 25, } \\
2015\end{array}$ & Typhoon "Goni" & Rockfalls and landslides in the upper part of Guam Tunnel, Seomyeon, and Uleung-gun \\
\hline $\begin{array}{l}\text { Nov. 13, } \\
2015\end{array}$ & $\begin{array}{l}\text { Localized heavy } \\
\text { rainfall }\end{array}$ & Landslides near Namyang Tunnel, Seomyeon, and Uleung-gun (scale about $200 \mathrm{~m}^{3}$ ) \\
\hline $\begin{array}{l}\text { Feb. 15, } \\
2016\end{array}$ & Freeze thawing & Rockfalls in the vicinity of Manira Hotel, Uleung-eup, and Uleung-gun (scale about $500 \mathrm{~m}^{3}$ ) \\
\hline $\begin{array}{l}\text { Aug. 30, } \\
2016\end{array}$ & Typhoon "Lionrock" & $\begin{array}{c}\text { Debris flows and landslides in the upper part of Piam (rock shed) Tunnel, Gadu-bong, Uleung-eup, } \\
\text { and Uleung-gun }\end{array}$ \\
\hline
\end{tabular}

had a high correlation with rainfall in the summer season and snowfall in the winter season. Out of the cases, the steep slope disasters occurring from July to September in the summer season showed a high correlation with typhoons and localized heavy rains.

Figure 3 shows rainfall information during the months when steep slope disasters occurred, as presented in Table 1. The bar graph is for the daily rainfall, the line graph for the accumulated rainfall, and the dotted line for the occurrence dates. The accumulated rainfall ranged from 85 to $438 \mathrm{~mm}$ for two weeks before the disaster occurred, and the maximum daily rainfall ranged from 40.0 to $220.5 \mathrm{~mm}$ during the disaster. In the case of the steep slope hazard on February 15, 2016, the maximum daily rainfall was the lowest at $40 \mathrm{~mm}$. However, the melting of the frozen groundwater may have caused it.

2.3. Numerical Simulation. The two-dimensional modeling is conducted using KANAKO-2D, a widely used model in calculating flow rate, flow depth, and sediment concentration, reflecting debris flow distribution to analyze the influence range of debris flow. The model is based on
Takahashi's diluent model in deriving governing equations [35].

Momentum and continuity equations are the basis for the analysis. The momentum equation of sediment and water flow mixture is indicated as follows:

$$
\begin{aligned}
& \frac{\partial u}{\partial t}+u \frac{\partial u}{\partial x}+v \frac{\partial u}{\partial y}=g \sin \theta_{w x}-\frac{\tau_{x}}{\rho h}, \\
& \frac{\partial v}{\partial t}+u \frac{\partial v}{\partial x}+v \frac{\partial v}{\partial y}=g \sin \theta_{w y}-\frac{\tau_{y}}{\rho h},
\end{aligned}
$$

where $u$ is the $x$-axis direction flow velocity, $v$ is the $y$ axis direction flow velocity, $t$ is time, $g$ is the acceleration of gravity, $h$ is the flow depth, $\rho$ is the water density, $\theta_{w x}$ and $\theta_{w y}$ are the flow surface gradients in the $x$-axis and $y$-axis directions in each, and $\tau_{x} \tau_{y}$ are the riverbed shearing stresses in the $x$-axis and $y$-axis directions in each.

The continuity equation of the flow mixture is indicated as follows. Moreover, the sum of the change in flow depth over time and the change in flow rate with a spatial transition can be explained with erosion and deposition velocity: 


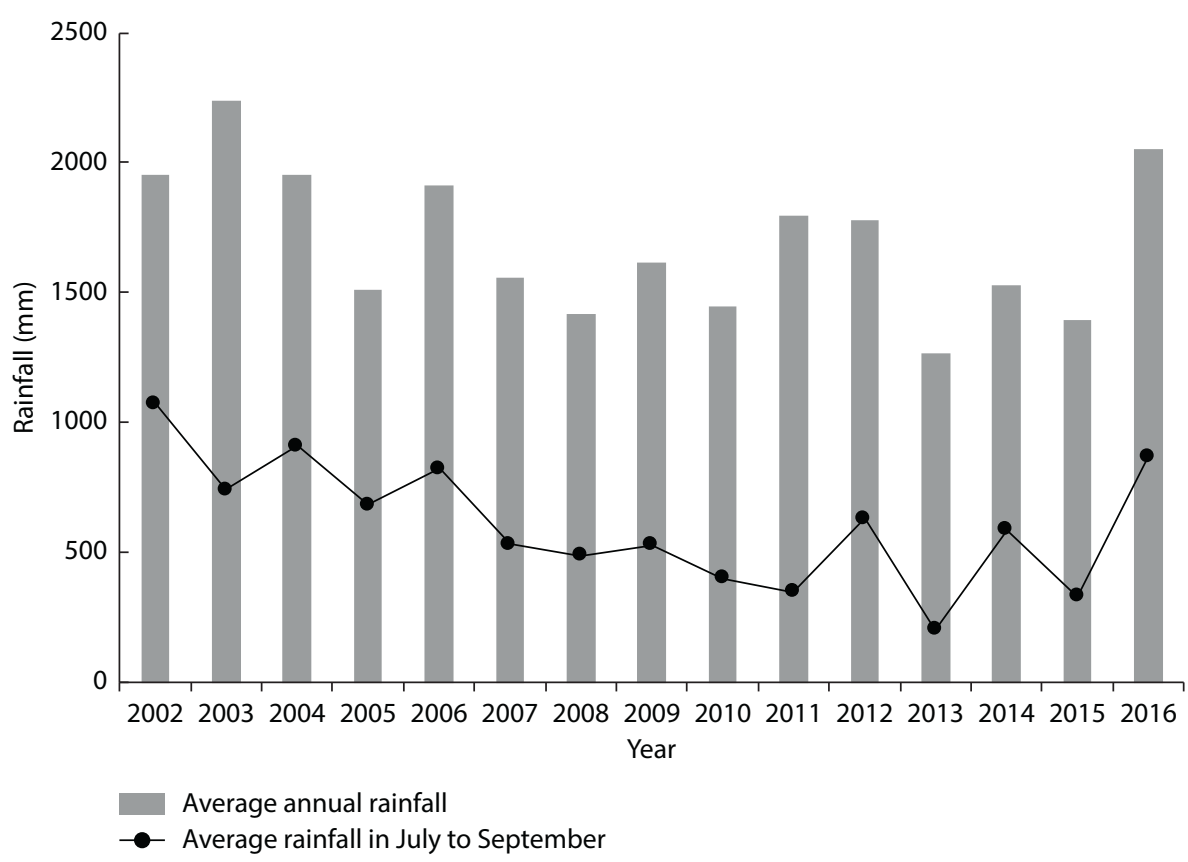

FIgURE 2: Average annual rainfall in Ulleung-do Island for 15 years and average rainfall pattern from July to September.

$$
\frac{\partial h}{\partial t}+\frac{\partial u h}{\partial x}+\frac{\partial v h}{\partial y}=\mathrm{i}
$$

where $i$ is the erosion and deposition velocity.

The continuity equation of sediment particles, such as in the continuity equation of flow mixture, keeps the attribute of continuity for sediment particles and can be expressed by multiplying the flow depth with sediment concentration, as indicated below:

$$
\frac{\partial C_{s} h}{\partial t}+\frac{\partial C_{s} u h}{\partial x}+\frac{\partial C_{s} v h}{\partial y}=\mathrm{i} C_{s} *
$$

where $C_{s}$ is the sediment concentration in the flow and $C_{s}$ * is the maximum sediment concentration in the bed.

The equation for the bed varying with erosion and deposition of sediment particles and water flow mixture can be expressed with the equation of bed variation:

$$
\frac{\partial z}{\partial t}+\mathrm{i}=0
$$

where $z$ is the erosion or deposition thickness of the bed measured from the original bed surface elevation.

In a fixed bed, $z$ equals 0 . The sediment in a fixed bed should be contained in the flow parts when erosion occurs. However, there is no sediment in a fixed bed.

The peak rate of debris flow is calculated using the sediment discharge of actual measurement. However, the study could not accurately calculate the sediment discharge for a stream section in the study area because it was covered with a road at the lower part of the natural mountain stream. Thus, the study used a rational method, the sediment discharge calculation formula presented by Chow et al. [36], to estimate debris flow's peak rate. The rational method is mainly used for a subbasin with a 120 ha area or less to calculate the outflow rate [37]. It is advantageous when there is no available data on the outflow rate for a target stream, and the rational method is as follows:

$$
Q=\frac{\text { CIA }}{3.6},
$$

where $Q$ is the peak discharge $\left(\mathrm{m}^{3} / \mathrm{s}\right), C$ is the runoff coefficient (reflecting basin characteristics including topography, soil, vegetation, and land use), $A$ is the catchment area $\left(\mathrm{km}^{2}\right)$, and $I$ is the maximum rainfall intensity with a frequency of 100 years, provided by the Korea Precipitation Frequency Data Server run by the Ministry of Land, Infrastructure and Transport (MOLIT) of South Korea [38].

From August 28 to 30, 2016, Ulleung-do Island experienced a record rainfall of $398.1 \mathrm{~mm}$ because of the impact of typhoon "Lionrock." The precipitation recorded the highest ever in the history of Korea's meteorological observation, leading to landslides and debris flow disasters in 10 sites. Out of the multiple sites that experienced steep slope disasters, the study selected one area damaged from debris flow that occurred in Sadong-ri, Ulleung-eup, and Ulleunggun (Figure 4).

As mentioned above, as a volcanic island in the study area, it is a condition prone to landslides as it is composed of sedimentary rocks with a high topographic gradient and high porosity as internal factors. When the cumulative rainfall was $490.2 \mathrm{~mm}$, a landslide occurred, and at this time, a landslide warning was issued. Due to the landslide, an amount of sediment did not form a natural dam and flowed down the mountain stream.

Landslides occurred approximately $750 \mathrm{~m}$ upstream from the outflow point where the mountain boundary bordered the mountain stream (Figure 4(a)). Those were followed by sediments, including soil, rock mass, and falling 


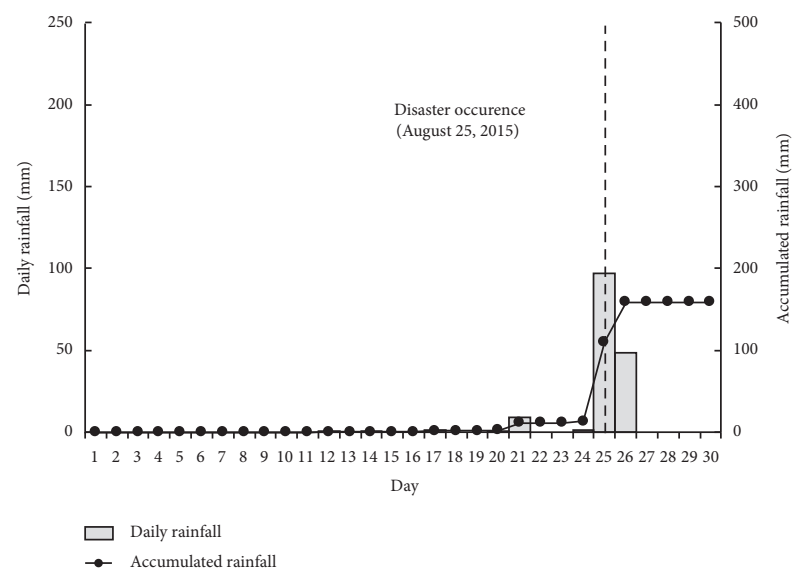

(a)

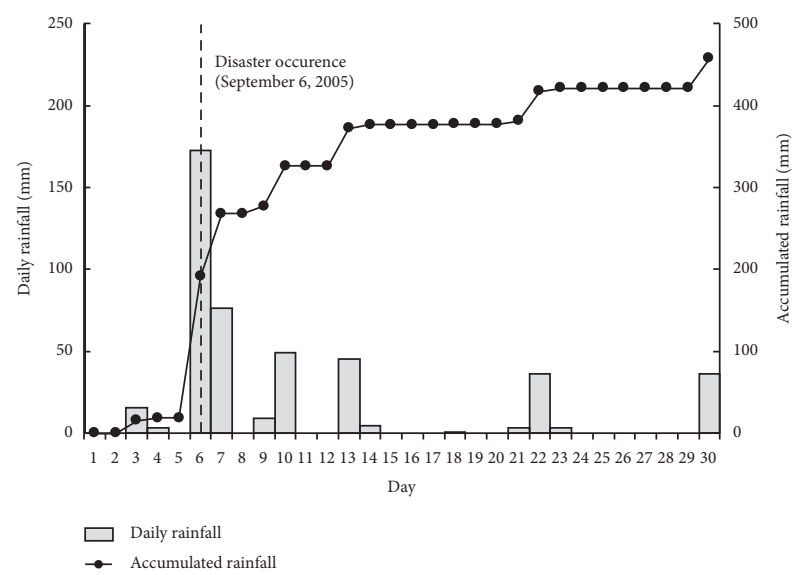

(c)

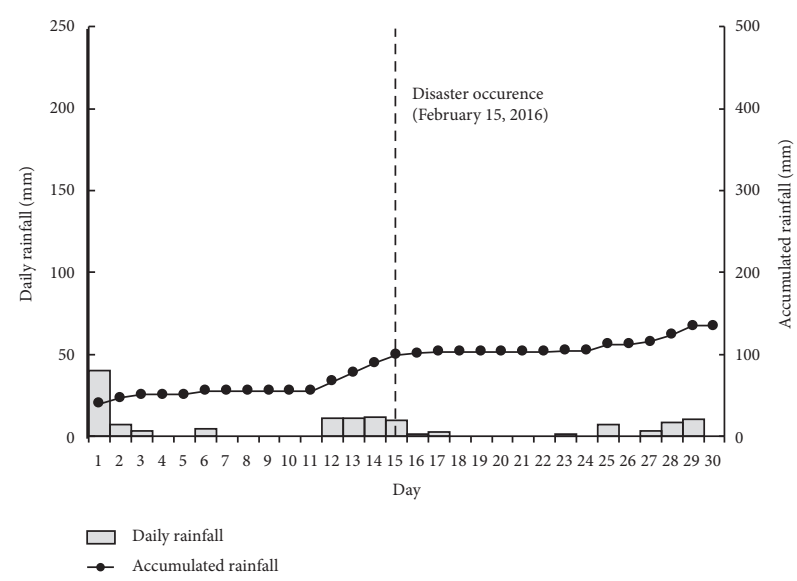

(e)

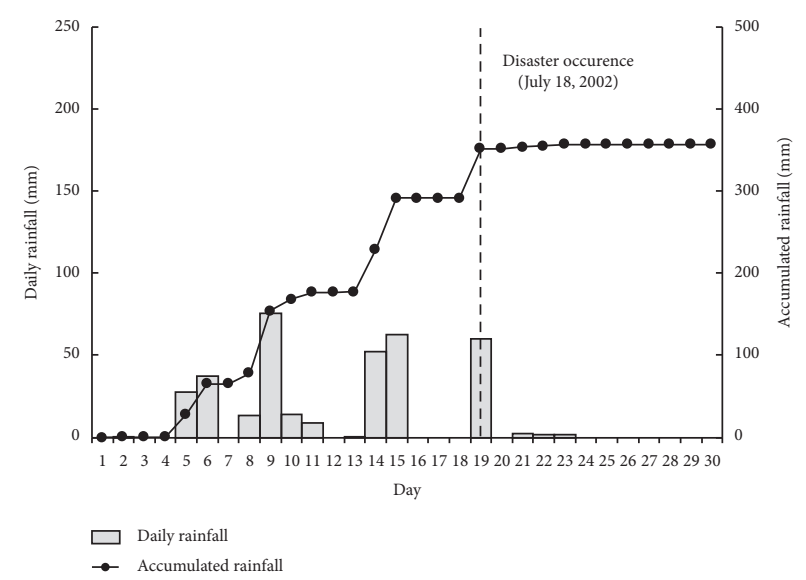

(b)

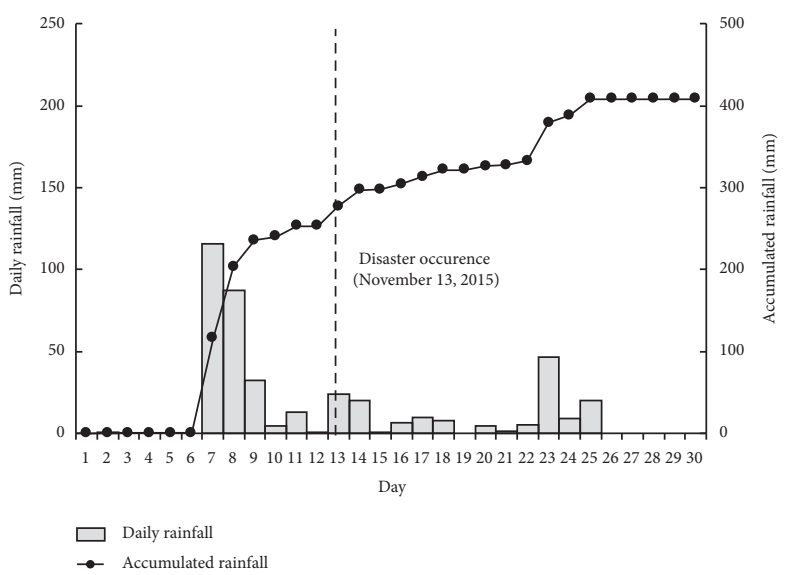

(d)

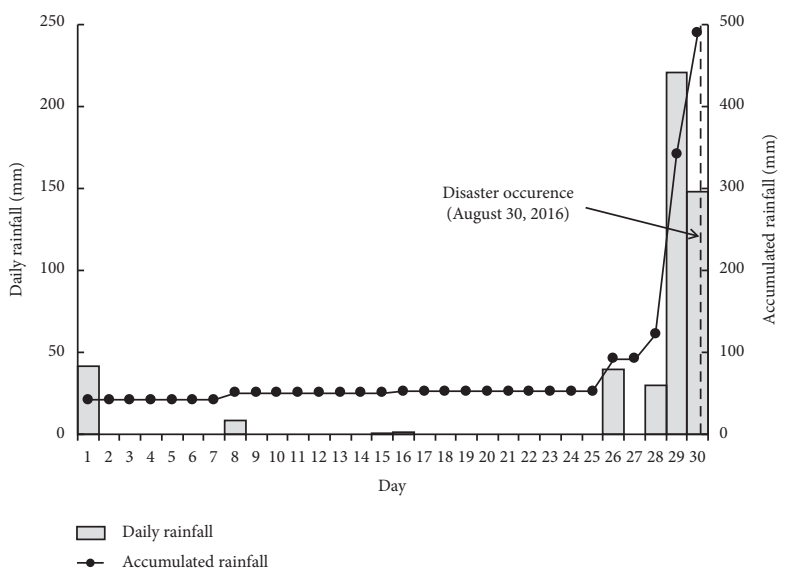

(f)

FIGURE 3: Analysis of the changing pattern for daily and accumulated rainfall before and after the date of disaster occurrence. (a) August 2015. (b) July 2002. (c) September 2005. (d) November 2015. (e) February 2016. (f) August 2016.

trees, that moved downward along the mountain stream and changed to debris flow. Moreover, soils were shielded at the stream's starting point with a road at $120 \mathrm{~m}$ upstream from the outlet (Figure 4(b)), causing sediments to overflow into roads in populated areas (Figure 4(c)). Afterward, an opentype check dam with a lattice structure was installed $300 \mathrm{~m}$ downstream from the trigger point where the debris flow began, so further damage from debris flow in the mountain stream basin can be reduced (Figure 4(d)).

The scope highlighted with a black dotted line (Figure 4(c)) is where the stream, once running, is covered with a road. The debris flow's sediments blocked the cover structure's opening, which caused the water and sediments to overflow into roads and houses. 


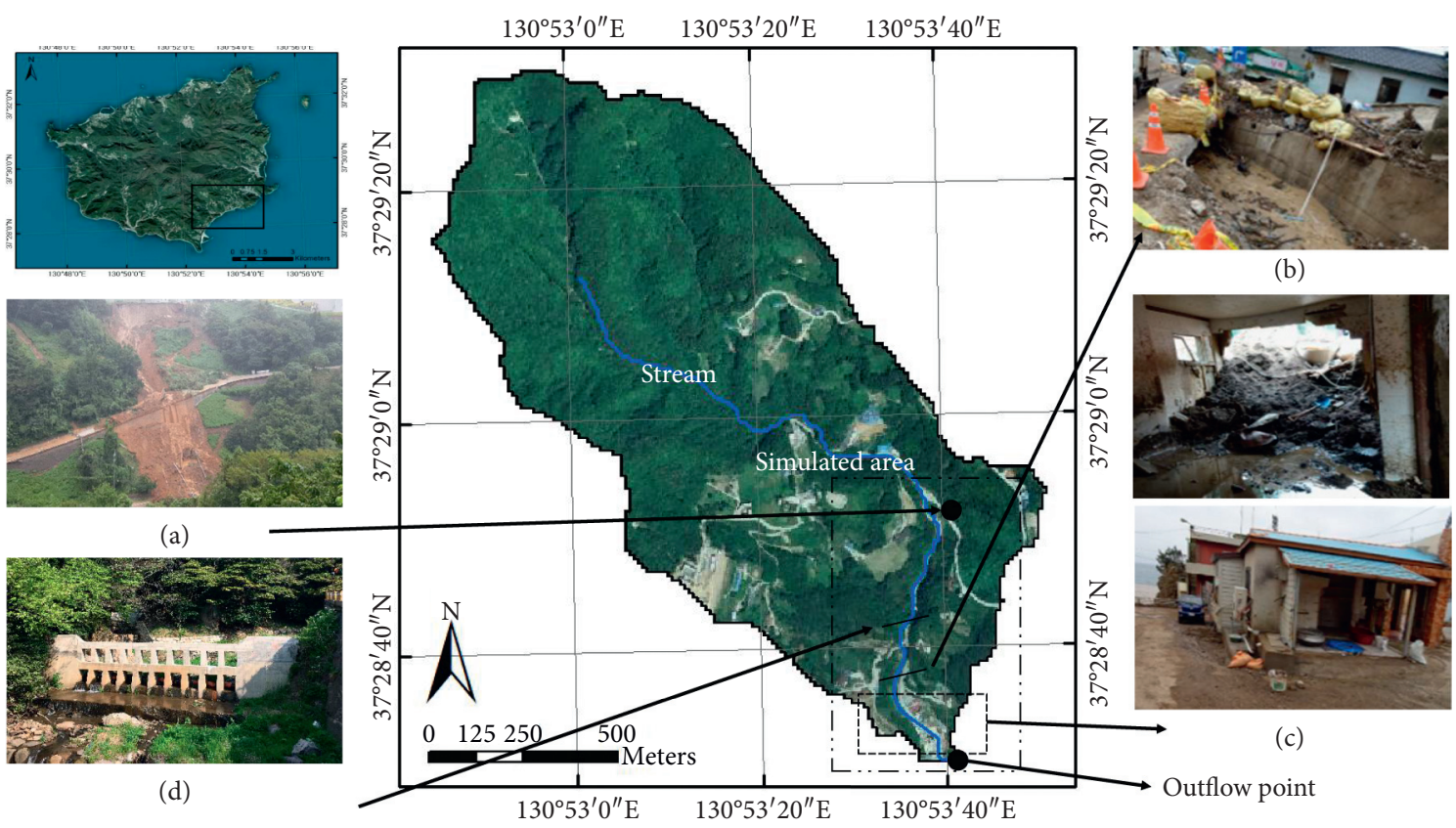

Figure 4: Debris flow occurrence in the study area and the damage inflicted. (a) Trigger point. (b) Covered open channel. (c) Damaged area. (d) Open-type check dam (installed after debris flow).

The study used the KANAKO-2D numerical model based on spatial analysis information using GIS to assess the changes in debris flow rate and flow depth at the installation point and the covered stream's front-end to analyze the effect of the installed open-type check dam.

The variables used in the numerical model are as follows. For the runoff coefficient $(C), 0.40$ of the rugged forest area was applied because the area is mountainous, and the average slope of the section having experienced landslides is over $20^{\circ}$. For the rainfall intensity $(i)$, the study applied $152.5 \mathrm{~mm} / \mathrm{hr}$ of the maximum rainfall intensity of $10 \mathrm{~min}$ for the 100-year frequency provided by the Korea Probability Rainfall Information System [30] with $1.49 \mathrm{~km}^{2}$ of the basin area. The peak discharge of debris flow calculated with the rational method for each of the values is shown in Figure 5, and the maximum peak discharge was estimated to be $25 \mathrm{~m}^{3} / \mathrm{s}$.

Table 2 shows the input conditions of the KANAKO-2D numerical model for the debris flow analysis basin and the DEM was applied in $5 \mathrm{~m}$ units. For this modeling, the debris flow concentration was assumed to be $40 \%$ and the erodible bed's depth to be $1 \mathrm{~m}$. Because there is no more erosion from the starting point of the covered stream, the movable bed layer's thickness was applied as $0 \mathrm{~m}$ for the analysis.

Figure 6 shows the application of the numerical model according to the conditions of the check dam. After the debris flow event, an open-type check dam was installed approximately $450 \mathrm{~m}$ upstream from the outflow point using concrete materials to reduce secondary damage. The opentype check dam is $20 \mathrm{~m}$ long and $3 \mathrm{~m}$ high, and $1 \mathrm{~m} \times 1 \mathrm{~m}$ openings were set in tens for two stages with a $0.5 \mathrm{~m}$ distance between the openings. It is challenging to reflect the check



Figure 5: Debris flow peak discharge calculated by rationale method.

TABLE 2: KANAKO-2D input conditions for debris flow simulation analysis.

\begin{tabular}{lc}
\hline Input condition & Value \\
\hline DEM & $5 \mathrm{~m} \times 5 \mathrm{~m}$ \\
Peak discharge & $25 \mathrm{~m}^{3} / \mathrm{s}$ \\
Sediment concentration & $40 \%$ \\
Thickness of the movable bed layer & $1 \mathrm{~m}$ \\
Thickness of the movable bed layer (covered stream) & $0 \mathrm{~m}$ \\
\hline
\end{tabular}

dam's actual shape on the numerical model's $5 \mathrm{~m}$ grid. Therefore, it is calculated as the penetration ratio of debris flow discharge at the check dam location. The $20 \mathrm{~m}$ long check dam is calculated at four cells. The penetration ratio is $100 \%$ in the absence of the check dam case, the penetration ratio is $0 \%$ in the case of a closed-type check dam case, and 

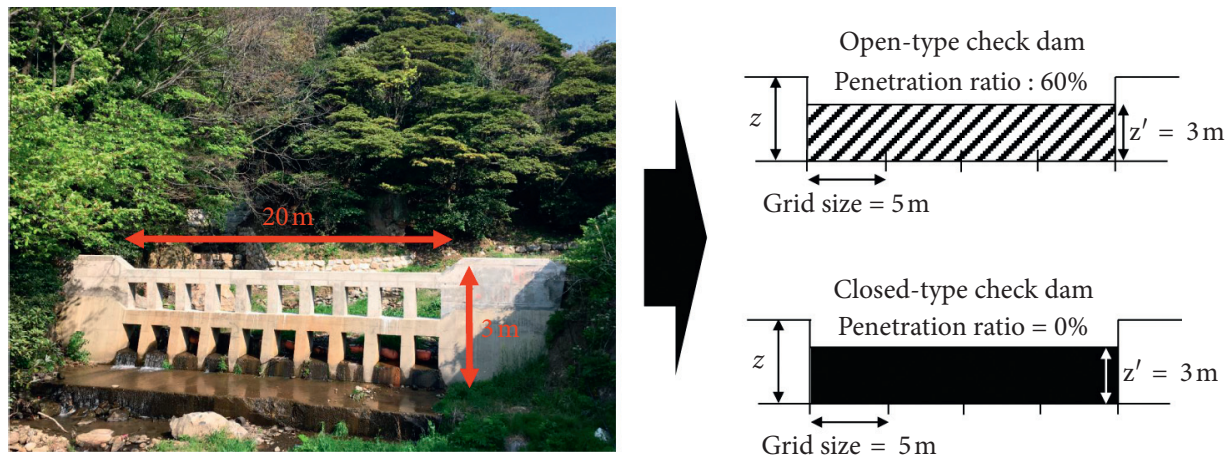

Figure 6: Application of the check dam.

the penetration ratio is $60 \%$ in the case of an open-type check dam case. The penetration ratio is set as the opening crosssectional area ratio to the check dam's total cross-sectional area.

\section{Results}

The basin's spatial analysis results in the study area using the 1:5,000 digital topographic map are shown in Figure 7, while the basin's characteristics are presented in Table 3 . The basin area is approximately $1.49 \mathrm{~km}^{2}$, with a mean elevation of $330.3 \mathrm{~m}$. The minimum altitude is $5 \mathrm{~m}$ to the outflow point, while the maximum altitude is $845 \mathrm{~m}$. The linear space between the two points has an approximate length of $2.2 \mathrm{~km}$, which is short for such a high altitudinal gap and is very steep with an average slope of $66^{\circ}$.

The scope of debris flow occurrence and damage covers the lower part of the study area, and the black dotted box highlights the basin area for debris flow simulation (Figure 7). The slope at the point of debris flow occurrence is steep, with an inclination of $64^{\circ}$. Because the debris flowed with running water along the mountain stream, direct and indirect damage affected the downstream area, where roads, houses, and other facilities are located.

The numerical simulation results for the debris flow area with the deposition height and maximum flow velocity are shown in Figure 8. The spread area of debris flow identified through the analysis was $17,325 \mathrm{~m}^{2}$, which was very similar to the actual area measuring $19,000 \mathrm{~m}^{2}$. The average deposition height was $0.51 \mathrm{~m}$, and the maximum deposition height was $2.9 \mathrm{~m}$, with higher heights mostly found downstream. The average flow velocity was $1.23 \mathrm{~m} / \mathrm{s}$, and the maximum was $3.9 \mathrm{~m} / \mathrm{s}$ at $300 \mathrm{~m}$ upstream from the outflow point. It was analyzed that flow velocity increases with the narrow mountain stream's influence, a significant difference between altitudes in the stream and the topography characterized by the steep slope of $64^{\circ}$.

As shown in Figure 8, the velocity and depth of debris flow decrease once it faces the covered stream section that starts at $120 \mathrm{~m}$ upstream from the outflow because of its spread. This interpretation suggests that the simulation is close to the actual event, where the debris flow overflows into the road and spreads downward when the opening, which is the starting point of the stream section covered with a road, is closed.
Figure 9 shows the surrounding roads that collapsed with the overflow of debris at the covered stream point and the houses beneath were destroyed because of the debris' inflow and sliding materials. The covering structure's size was measured as $1.2 \mathrm{~m}$ in height and $3 \mathrm{~m}$ in width on the site. The sediments suddenly blocked the opening to interrupt the debris flowing along the stream to cause the overflow, which led to the diffusion and accumulation of such materials in the road and directly damaged roads, houses, and other facilities. As a result of the field study, it was found that the height of debris flow damage traced around the destroyed houses was about $2 \mathrm{~m}$, which is similar to the analyzed height of downstream debris flow deposition.

Upon applying rainfall intensities and the debris flow rates analyzed above, debris flow discharge and flow depth were estimated at observation point 1 (Ob. 1) and observation point 2 (Ob. 2) before and after the check dam installation.

Figure 10 shows the stream's longitudinal section, where the debris flow occurred in the study area. The point where the debris flow started was marked zero $(0)$ at the $x$-axis and was located at $673 \mathrm{~m}$ altitude. The starting point is where soils, rocks, and falling trees have been washed away because the collapsed mountain slope is flowing in. Such sliding materials met the stream $90 \mathrm{~m}$ from the starting point. In other words, they became a form of debris flow when they encountered the stream. The open-type check dam was installed $300 \mathrm{~m}$ from the starting point, and the stream right down the dam was set as Ob. 1. Meanwhile, Ob. 2 was defined from approximately $600 \mathrm{~m}$ downstream to the stream's fore-end covered with a road.

Figure 11 shows the changes in the debris flow discharge analyzed at observation point 1 (Ob. 1), presented in Figure 10. The maximum discharge of debris flow at Ob. 1 was $8.69 \mathrm{~m}^{3} / \mathrm{s}$ for "no check dam," $4.48 \mathrm{~m}^{3} / \mathrm{s}$ for "open-type check dam," and $3.22 \mathrm{~m}^{3} / \mathrm{s}$ for "closed-type check dam." In the "open-type check dam" condition, the maximum rate of debris flow was found to be reduced by about $48.5 \%$ from the level of the "no check dam," while the "closed-type check dam" condition has the maximum rate of debris flow reduced by $62.9 \%$, indicating that the closed-type was more effective than the open-type. The debris flow time capturing was counted, starting from its arrival at the check dam until it ended up overflowing. The time of debris flow captured in 


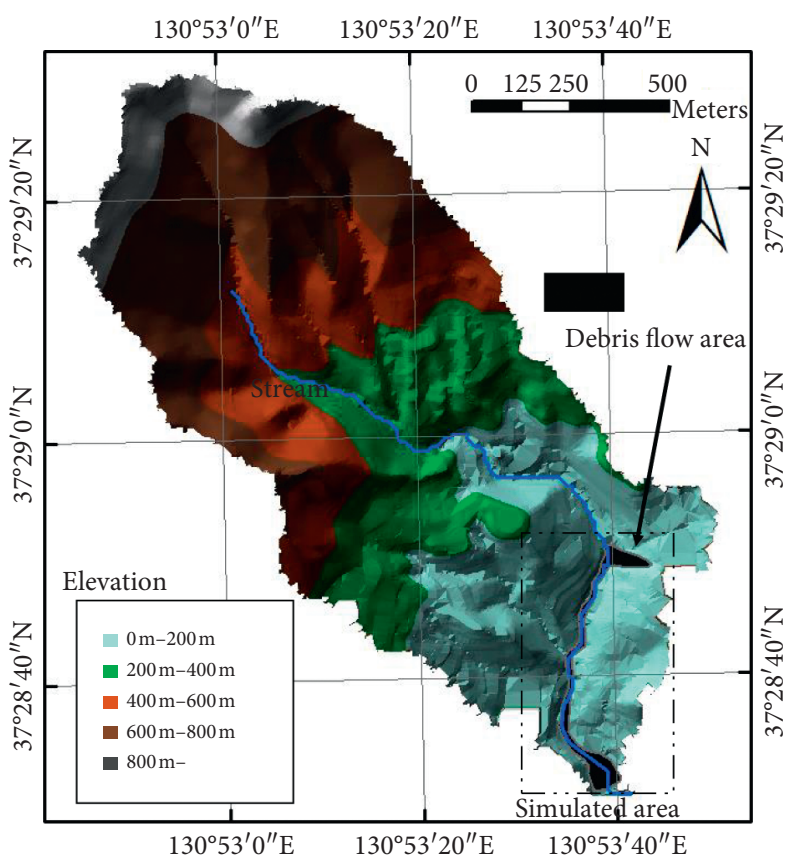

(a)

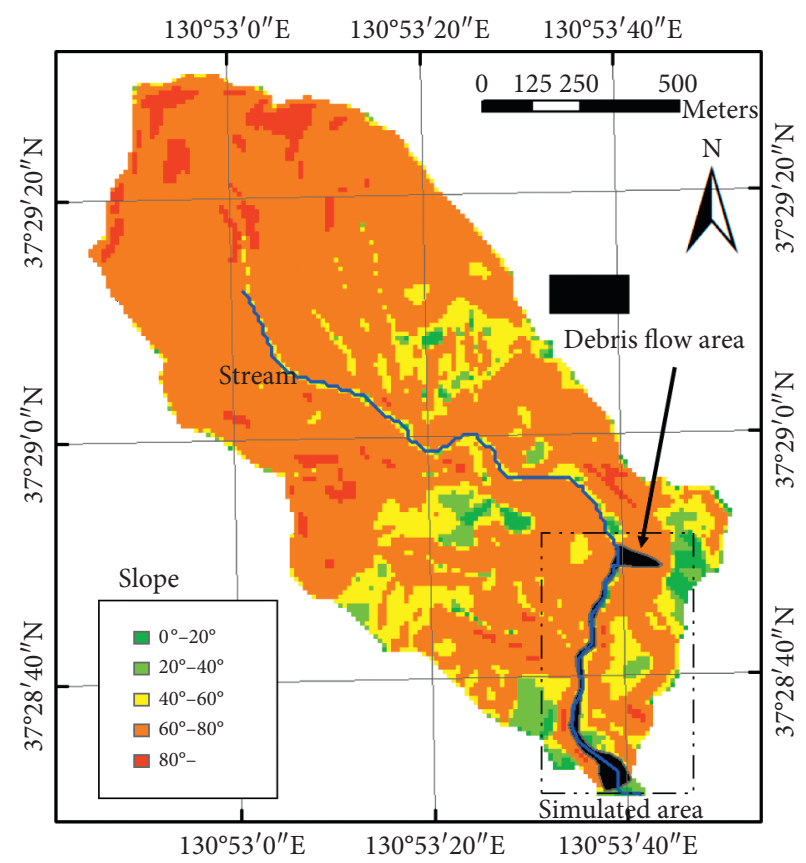

(b)

Figure 7: Spatial analysis for the study area's basin.

TABLE 3: Basin information of the study area.

\begin{tabular}{lc}
\hline Parameters & Values \\
\hline Basin area & $1.49 \mathrm{~km}^{2}$ \\
Basin maximum elevation & $845 \mathrm{~m}$ \\
Basin minimum elevation & $5 \mathrm{~m}$ \\
Basin mean elevation & $330.3 \mathrm{~m}$ \\
Basin mean slope & $66^{\circ}$ \\
Stream length & $2.1 \mathrm{~km}$ \\
Debris flow area & $0.019 \mathrm{~km}^{2}$ \\
Mean slope of the debris flow area & $48^{\circ}$ \\
\hline
\end{tabular}

the check dam was approximately $108 \mathrm{sec}$, meaning that it took $108 \mathrm{sec}$ longer for debris flow to arrive downstream of the mountain torrent.

Figure 12 shows the results of comparing debris flow depths at Ob. 2 at the fore-end of the covered area's opening. Because Ob. 2 can be regarded as the beginning of a residential area, the discharge and flow depth of debris flow are significant.

The time taken for a debris flow to arrive at the coverpoint was $308 \mathrm{sec}$ without a check dam, $342 \mathrm{sec}$ with the open-type installed, and $474 \mathrm{sec}$ with the closed-type installed. Assuming that the average flow depth is the mean calculated for the time interval from a point when the debris flow starts to another point when the flow depth becomes $0.1 \mathrm{~m}$, it is $0.46 \mathrm{~m}$ without a check dam, $0.31 \mathrm{~m}$ with the open-type installed, and $0.22 \mathrm{~m}$ with the closed-type installed. For all three conditions, the average flow depth was lower than $1.2 \mathrm{~m}$, which is the cover structure's height. In addition, the maximum flow depth was $1.67 \mathrm{~m}$ without a check dam, $0.84 \mathrm{~m}$ with the open-type installed, and $0.38 \mathrm{~m}$ with the closed-type installed. In the absence of a check dam, the debris flow depth was higher than $1.2 \mathrm{~m}$, which is the height of the cover structure, and thus the result was similar to what was seen on the site with the overflowing debris sediments causing direct and indirect damage to roads and houses.

\section{Discussion}

After a debris flow occurs in the study area, an open-type check dam was installed at Ob. 2. To verify the effectiveness of the installed open-type check dam, a numerical analysis was performed for three conditions: "no check dam;" "closed-type check dam" installation; and "open-type check dam" installation. Afterward, a comparison of debris flow discharges and depths was conducted between the three conditions. For the open-type check dam, local characteristics on the site were reflected, as shown in Figure 6.

When the check dam was installed, the discharge and flow depth of debris flow were reduced. However, the closedtype check dam installation reduced the discharge and debris flow depth more effectively than the open-type check dam installation. In addition, the time for the debris flow to reach the residential area was slower on the closed-type check dam installation rather than open-type check dam installation, about 100 seconds. A slower debris flow would give residents more time to evacuate.

Although the closed-type check dam is more effective in reducing debris flow than the open-type check dam, the open-type check dam was installed in the study area. Therefore, confirming whether the open-type check dam can prevent debris flow damage in residential areas is necessary. However, based on the simulation results' functional aspect, the closed-type check dam installation is more appropriate 


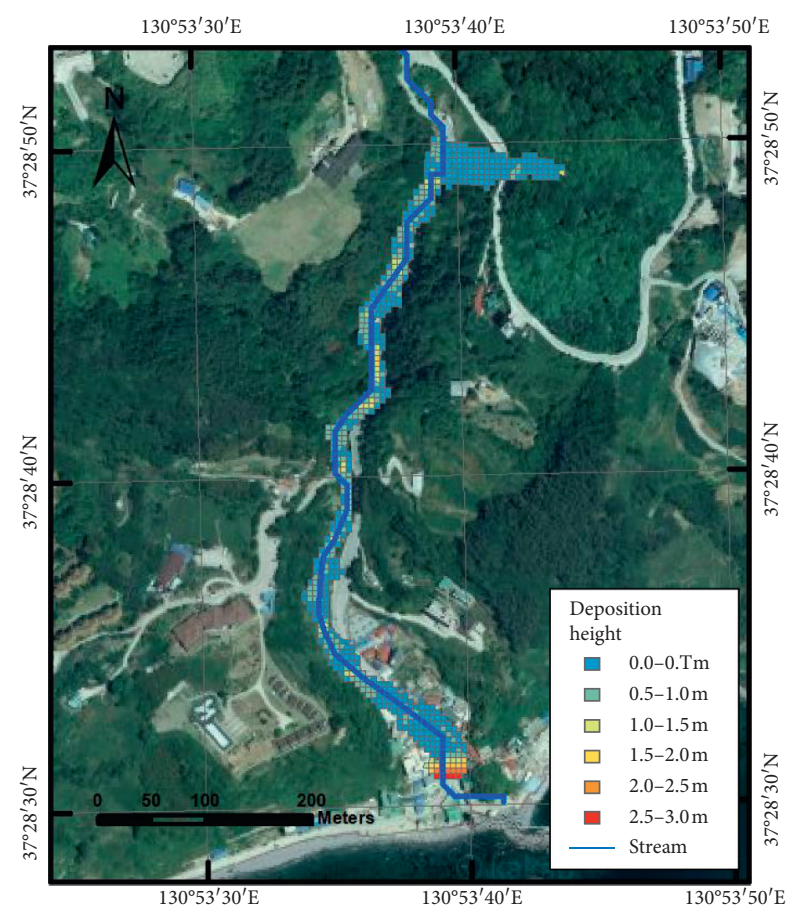

(a)

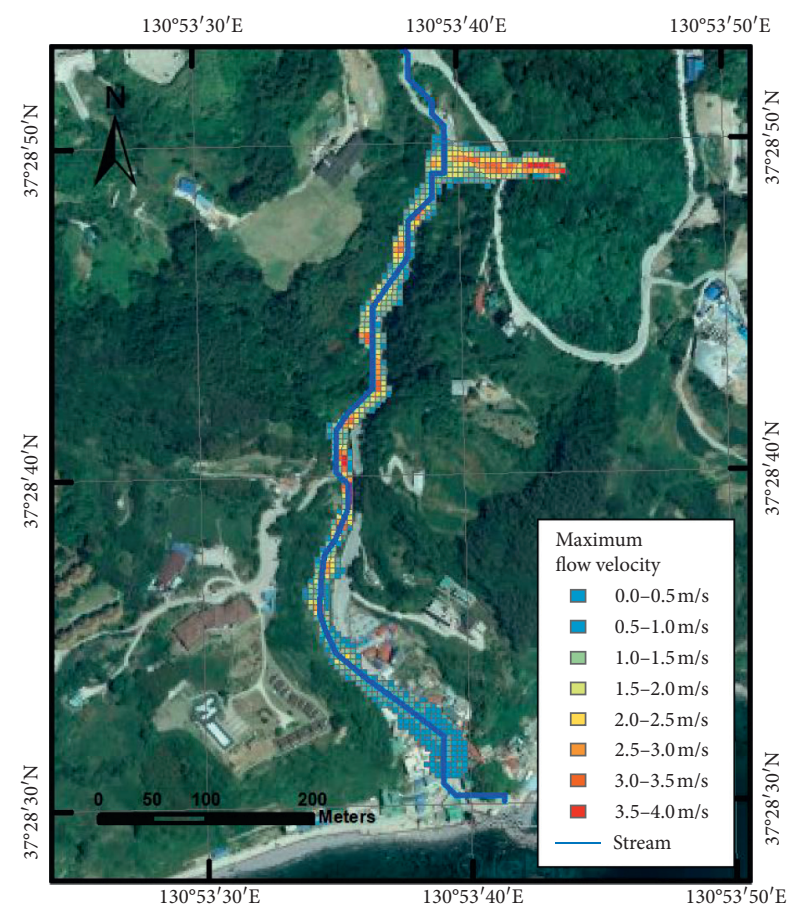

(b)

FIgURE 8: Results of KANAKO-2D numerical analysis for debris flow area: (a) deposition height of debris flow; (b) maximum flow velocity of debris flow.

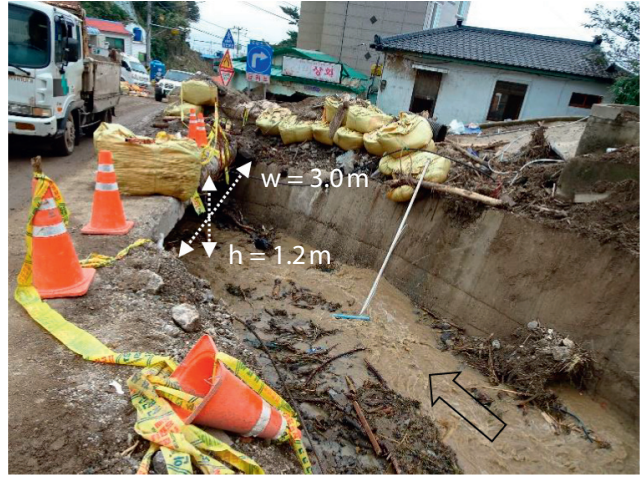

(a)

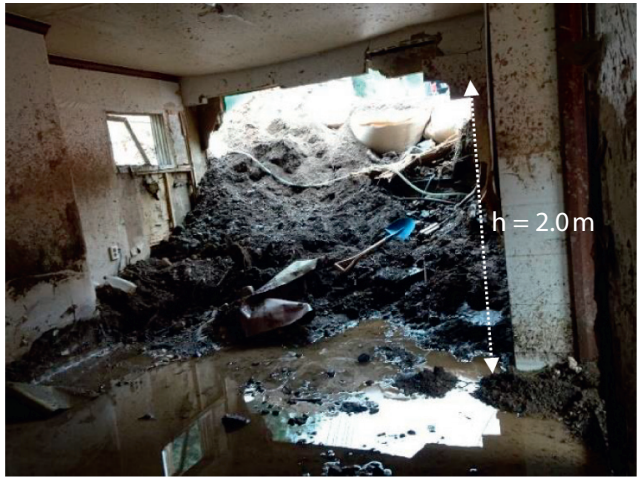

(b)

FIGURE 9: Images of damaged road and house with the overflow of debris flow at the covered stream section: (a) collapse of the opening, which is the starting point of the stream section covered with a road; (b) destroyed house caused by debris flow.

than an open-type check dam. Moreover, the functional and environmental aspects should also be considered in the dam installation because aquatic plants and fish species live in the stream. Installing an open-type check dam is expected to incur to the residential area because the dam's maximum depth is lower than $1 \mathrm{~m}$, the height of flow coverage at the beginning of a residential area (Ob. 2). Thus, installing an open-type check dam is considered an environmental decision rather than a functional decision as long as it does not damage the residential area.

Increasing the covered structure's size (Ob. (2) is necessary to increase the installed open-type check dam's effectiveness because a larger debris flow may occur. In addition, the installed open-type check dam's steep slope and limited capacity can cause a large amount of soil to collapse from the basin's upper portion and overcome the residential area. Thus, a debris flow discharge could be higher than the covered structure's cross-section at $3 \mathrm{~m} \times 1.2 \mathrm{~m}$ (width $\times$ height). This study compared the flow depth of the debris flow and the cover section's height, but further research is needed to determine the cover section's optimal size. In the numerical model, the grid's size, the check dam's penetration ratio, and the spread of debris flow due to the covered stream's influence are necessary. 


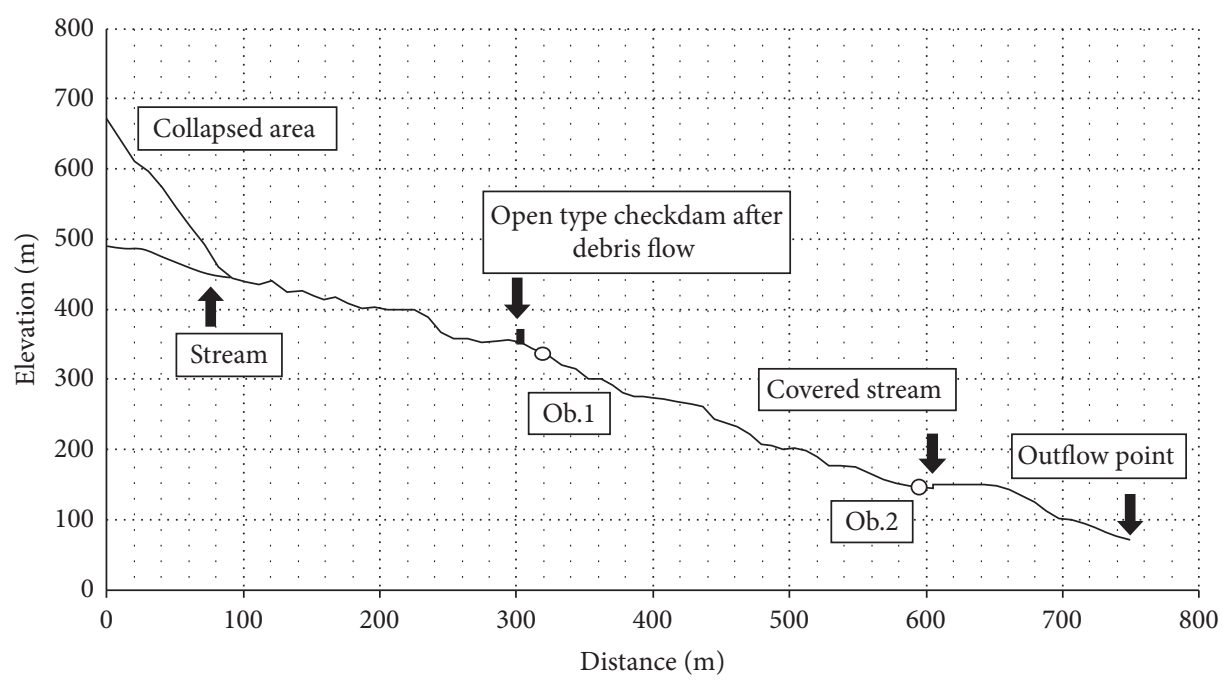

FIGURE 10: Longitudinal profile of the analysis section and status of modeling comparison points of observation points (Ob. 1 and Ob. 2) assess the open-type check dam's functions.

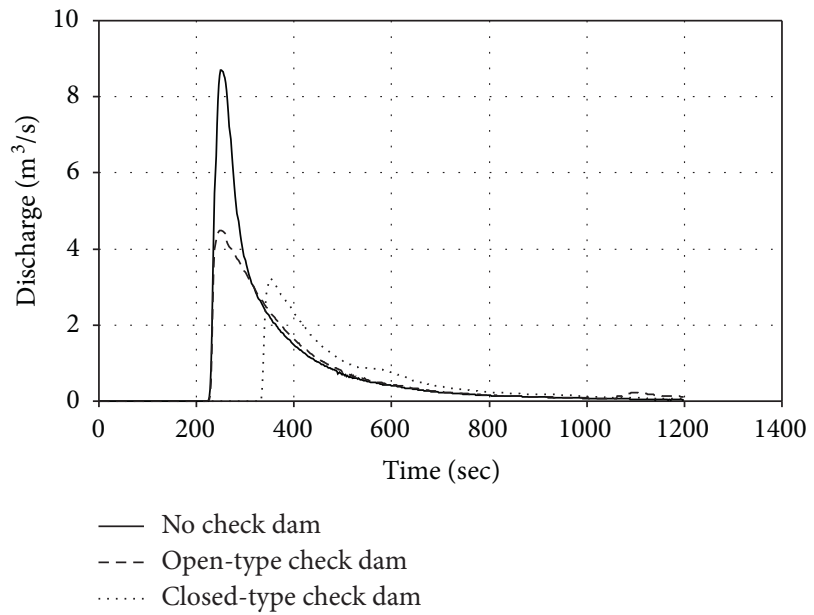

FIGURE 11: Observation point 1 with or without a check dam and debris flow rates comparison between the check dam types.

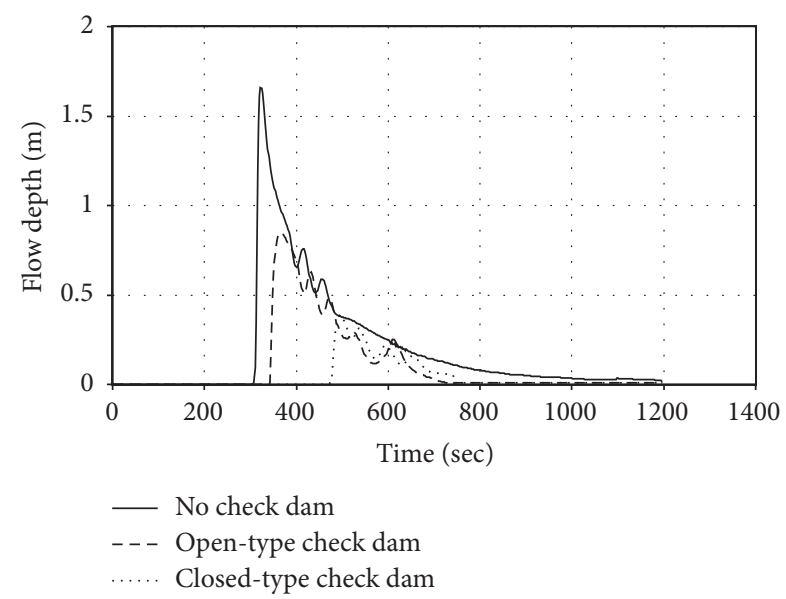

Figure 12: Observation 2 with or without a check dam at the frontend of cover structure and comparison of changes in maximum flow depth between the types.
Moreover, soil properties survey, expected slope failure areas, and suitable locations for additional check dam installation on the actual site are necessary.

The selection of the check dam and the covered structure's size could be important information in making debris flow risk map because it provides information that helps reduce the potential damage inflicted by debris flow on residential areas. The development of a debris flow risk map for the entire Ulleung-do is possible by gathering such information. Creating a debris flow risk map for the entire Ulleung-do area requires geological, rainfall, and topographical information to predict the area's potential damage. The debris flow risk map is then updated by applying the optimal countermeasures to reduce the damage that the debris flow caused to the residential area. Finally, the debris flow risk map can be enhanced by adding information from residents and related organizations. The debris flow risk map that can be created using this study results can help achieve sustainable living, such as identifying suitable areas for urban development and land use planning, among others. This information could be considered in line with the United Nations Office for Disaster Risk Reduction's (UNDRR) Sendai Framework Action Protocol. Residents' opinions, data from public institutions, and research results are needed to understand disaster risks. However, strengthening regional governance for systematic management is essential, and not just the technology to recognize and predict dangers, to reduce disaster risks and contribute to the residents' protection and sustainable development.

\section{Conclusions}

The Ulleung-do Island sees growing tourists all year round because of its local characteristics. Considering that disasters in mountain areas on the island occur mainly from March to November, the thawing season, it can be suggested that the inhabitants of Ulleung-do Island and the tourists are directly or indirectly affected by disasters throughout the year. 
This study analyzed the data on the history of disasters and mountain hazards and the damage they caused on the island since the 2000s. Moreover, the characteristics of the disasters occurring because of the debris flow event in 2016 were identified using the KANAKO-2D numerical model. The debris flow analysis showed that after the landslide, large amounts of sediments, including debris, rock fragments, and fallen tree residues, flowed into the mountain stream. Then, the debris was overflowing when it met the covered stream section to lead the spread of a debris flow along the road. The on-site debris flow survey results also indicated a similar pattern for the section before the covered stream to that of the flow analysis. For the section after it, flooding sediments with debris overflow at the cover's starting point caused significant damage to houses and stores located along the road.

As a result of assessing the effect of check dams in reducing damage from debris flow for each type, the debris flow rate at observation point 1 was reduced by $51.5 \%$ with the installation of the open-type check dam from the level of "no check dam" and by $62.9 \%$ with the installation of the closedtype check dam. At observation point 2 , the maximum flow depth was 1.67 without a check dam. However, the depth decreased by $0.84 \mathrm{~m}(49.7 \%)$ with the open-type check dam installed and by $0.38 \mathrm{~m}(77.4 \%)$ with the closed-type installed.

Based on these results, the installation of check dams in the mountain stream is considered effective in mitigating disasters caused by debris flow. Therefore, further analysis of potential debris flow hazards is required to select and apply a check dam type in consideration of local conditions and its effectiveness.

\section{Data Availability}

The data used to support the findings of this study are available from the corresponding author upon request.

\section{Conflicts of Interest}

The authors declare that there are no conflicts of interest regarding the publication of this paper.

\section{Acknowledgments}

This work was supported by the Korea Agency for Infrastructure Technology Advancement under the Ministry of Land, Infrastructure and Transport of the Korean Government (Project number: 21SCIP-C151408-03). Also, this work was supported by the National Research Foundation of Korea (NRF) grant funded by the Korea government (MSIT) (no. 2019R1F1A1058277).

\section{References}

[1] G. F. Wieczorek and F. Guzzetti, "A review of rainfall thresholds for triggering landslides," in Proceedings of the 2000 Plinius Conference, pp. 407-414, Cosenza, Italy, October1999.

[2] S. M. Ko, S. W. Lee, C.-Y. Yune, and G. Kim, "Topographic analysis of landslides in Umyeonsan," Journal of the Korean Society of Surveying, Geodesy, Photogrammetry and Cartography, vol. 32, no. 1, pp. 55-62, 2014.
[3] P. Passalacua, P. Belmont, D. M. Staley et al., "Analyzing high resolution topography for advancing the understanding of mass and energy transfer through landscapes: a review," Earth-Science Reviews, vol. 148, pp. 174-193, 2015.

[4] Y. Kim, M. Kim, B. Tamang, and J. Jin, "Slope behavior analysis using the measurement of underground displacement and volumetric water content," Journal of the Korean GeoEnvironmental Society, vol. 19, no. 9, pp. 29-36, 2018.

[5] J. J. Gan and Y. X. Zhang, "Analysis of model test rainfallinduced soil deposit landslide," Advances in Civil Engineering, vol. 2020, Article ID 6431247, 13 pages, 2020.

[6] X. Chu, Liang, L. Li, and Y. M. Cheng, "Risk assessment of slope failure using assumption of maximum area of sliding mass and factor of safety equal to unit," Advances in Civil Engineering, vol. 2019, Article ID 6268079, 11 pages, 2019.

[7] G. D. Bathrellos, H. D. Skilodimou, K. Chousianitis, A. M. Youssef, and B. Pradhan, "Suitability estimation for urban development using multi-hazard assessment map," Science of the Total Environment, vol. 575, no. 1, pp. 119-134, 2017.

[8] H. D. Skilodimou, G. D. Bathrellos, K. Chousianitis, A. M. Youssef, and B. Pradhan, "Multi-hazard assessment modelling via multi-criteria analysis and GIS: a case study," Environmental Earth Science, vol. 78, 2019.

[9] X. B. Gu, S. T. Wu, X. J. Ji, and Y. H. Zhu, "The risk assessment of debris flow hazards in banshanmen gully based on the entropy weight-normal cloud method," Advances in Civil Engineering, vol. 2021, Article ID 8841310, 11 pages, 2021.

[10] D. Salciarini, C. Tamagnini, P. Conversini, and S. Rapinesi, "Spatially distributed rainfall thresholds for the initiation of shallow landslides," Natural Hazards, vol. 61, no. 1, pp. 229-245, 2012.

[11] Y. H. Kim and K. W. Jun, "Analysis of debris flow disaster area according to location change of check dam using kanako-2d," Journal of the Korean Society of Safety, vol. 33, no. 1, pp. 128-134, 2018.

[12] Y. S. Song and W. P. Hong, "A case study on analysis of cause and characteristics of a landslide at the sedimentary rock area," The Journal of Engineering Geology, vol. 17, no. 2, pp. 101-113, 2007.

[13] B.-G. Chae, J.-H. Lee, H.-J. Park, and J. Choi, "A method for predicting the factor of safety of an infinite slope based on the depth ratio of the wetting front induced by rainfall infiltration," Natural Hazards and Earth System Sciences, vol. 15, no. 8, pp. 1835-1849, 2015.

[14] W. Y. Kim and B. G. Chae, "Characteristics of rainfall, geology and failure geometry of the landslide areas on natural terrains, Korea," The Journal of Engineering Geology, vol. 19, no. 3, pp. 331-344, 2009.

[15] Y. X. Wang, Y. J. Wang, L. Jiang, P. Sun, X. Lin, and S. Li, "Stability assessment of landslides in dahuaqiao reservoir area based on back analysis of slope monitoring," Advances in Civil Engineering, vol. 2019, Article ID 2563183, 15 pages, 2019.

[16] R. Vassallo, G. M. Grimaldi, and C. Di Maio, "Pore water pressures induced by historical rain series in a clayey landslide: 3D modeling," Landslides, vol. 12, no. 4, pp. 731-744, 2015.

[17] K.-S. Cha and T.-H. Kim, "Evaluation of slope stability with topography and slope stability analysis method," KSCE Journal of Civil Engineering, vol. 15, no. 2, pp. 251-256, 2011.

[18] A. Santoso, K. K. Phoon, and S. T. Quek, "Effects of soil spatial variability on rainfall-induced landslides," Computers \& Structures, vol. 89, no. 11-12, pp. 893-900, 2011. 
[19] A. Ali, J. Huang, A. V. Lyamin et al., "Simplified quantitative risk assessment of rainfall-induced landslides modelled by infinite slopes," Engineering Geology, vol. 179, no. 4, pp. 102-116, 2014.

[20] N. D. Yu, "Characteristics of unsaturated weathered soils with varying clay contents," Master's Thesis, Yonsei University, Seoul, South Korea, 2013.

[21] S. R. Lee and B. S. Jang, "Development and application of landslide analysis technique using geological structure," KOREA Spatial Information Society, vol. 10, no. 2, pp. 247261, 2002.

[22] I. Woo, "Artificial accelerated weathering of volcanic rocks from Ulleungdo island," The Journal of Engineering Geology, vol. 25, no. 4, pp. 499-510, 2015.

[23] G. B. Crosta, S. Imposimato, D. Roddeman, S. Chiesa, and F. Moia, "Small fast-moving flow-like landslides in volcanic deposits: the 2001 las colinas landslide (el salvador)," Engineering Geology, vol. 79, no. 3-4, pp. 185-214, 2005.

[24] P. P. Paudel, H. Omura, T. Kubota, and T. Inoue, "Spatiotemporal patterns of historical shallow landslides in a volcanic area, MT. Aso, Japan," Geomorphology, vol. 88, no. 1-2, pp. 21-33, 2007.

[25] M. Hürlimann, A. Ledesma, and J. Martí, "Characterisation of a volcanic residual soil and its implications for large landslide phenomena: application to Tenerife, Canary Islands," Engineering Geology, vol. 59, no. 1-2, pp. 115-132, 2001.

[26] M. K. Bae, K. W. Jung, and S. J. Park, "Development of landslide hazard map using environmental information system: case on the Gyeongsangbuk-do province," Journal of Environmental Science International, vol. 18, no. 11, pp. 1189-1197, 2009.

[27] Y.-G. Lee, B.-J. Kim, G.-U. Park, and B.-Y. Ahn, "Characteristics of precipitation and temperature at ulleung-do and dok-do, Korea for recent four years (2005 2008), Journal of Environmental Science International, vol. 19, no. 9, pp. 1109-1118, 2010.

[28] Y.-S. Seo, H.-S. Jang, and K.-Y. Kim, “Assessement of rockfall hazard in the northeast region of ulleung-do," The Journal of Engineering Geology, vol. 22, no. 3, pp. 353-363, 2012.

[29] Y.-M. Yi, D.-G. Yoo, N.-K. Kang, and B.-Y. Yi, "Distribution and origin of quaternary mass transport deposit in the Ulleung Basin, East Sea," Geophysics and Geophysical Exploration, vol. 17, no. 2, pp. 74-87, 2014.

[30] K.-B. Kim and M.-I. Kim, "Analysis of geological structure of volcanic rock mass in Ulleung-do using variations of magnetic anomaly," The Journal of Engineering Geology, vol. 28, no. 44, pp. 619-630, 2018.

[31] K.-B. Kim and M.-I. Kim, "Distribution of resistivity zones near Nari caldera, Ulleung-do, Korea, Inferred from modified dipole arrays," The Journal of Engineering Geology, vol. 29, no. 3, pp. 223-236, 2019.

[32] G.-B. Moon, Y.-M. You, H.-S. Yun, Y.-H. Suh, Y.-S. Seo, and Y. Baek, "Analysis of magnitude and behavior of rockfall for volcanic rocks in Ulleung-do," The Journal of Engineering Geology, vol. 24, no. 3, pp. 373-381, 2014.

[33] S.-J. Lee, J.-M. Lee, D.-G. Yoo, G.-E. Lee, and S.-C. Park, "Slope stability and development of debris flow deposit in the Ulleung basin, East sea," Economic and Environmental Geology, vol. 50, no. 2, pp. 129-143, 2017.

[34] C. K. Lee, S. W. Moon, H. S. Yun, and Y. S. Seo, "Infinite slope stability analysis based on rainfall pattern in Ulleung-do," The Journal of Engineering Geology, vol. 28, no. 1, pp. 11-24, 2018.
[35] T. Takahashi and H. Nakagawa, "Prediction of stony debris flow induced by severe rainfall," Journal of the Japan Society of Erosion Control Engineering, vol. 44, no. 3, pp. 12-19, 1991.

[36] V. T. Chow, D. R. Maidment, and L. W. Mays, Applied Hydrology, McGraw-Hill, New York, NY, USA, 1998.

[37] M.-I. Kim, J.-H. Kwak, and B.-S. Kim, "Assessment of dynamic impact force of debris flow in mountain torrent based on characteristics of debris flow," Environmental Earth Sciences, vol. 77, no. 14, p. 538, 2018.

[38] Ministry of Land, Infrastructure and Transport, "Korea precipitation frequency data server," 2021, http://k-idf.re.kr. 